\section{Congenital disorders
of the optic nerve:
excavations and
hypoplasia}

Abstract

The principal congenital abnormalities of the optic disc that can significantly impair visual function are excavation of the optic disc and optic nerve hypoplasia. The excavated optic disc abnormalities comprise optic disc coloboma, morning glory syndrome, and peripapillary staphyloma. Optic nerve hypoplasia manifests as a small optic nerve, which may or may not be accompanied by a peripapillary ring (the double ring sign). In addition, the optic disc cupping, which occurs as a sequel to some cases of periventricular leucomalacia, can arguably be classified as a type of optic nerve hypoplasia. All of these conditions can be unilateral or bilateral and can impair visual function mildly or severely. It is essential that children with poor vision due to any of these conditions are managed by treating refractive errors, giving occlusion

Tennent Institute of Ophthalmology

Gartnavel General Hospital Glasgow, UK

The Royal Hospital for Sick Children

Yorkhill

Glasgow, UK

Correspondence:

GN Dutton

Tennent Institute of Ophthalmology

Gartnavel General Hospital Great Western Road

Glasgow G12 OYN, UK

Tel: +441412112937

Fax: + 441412116290

E-mail: Sheena.MacKay@

NorthGlasgow.Scot.NHS.UK

Received: 4 September 2003

Accepted: 4 September 2003 therapy in selected cases, and optimising the conditions at home and at school in an attempt to ensure that impaired vision does not impede development or education. Eye (2004) 18, 1038-1048.

doi:10.1038/sj.eye.6701545

Keywords: optic nerve; congenital; hypoplasia; coloboma

\section{Introduction}

Congenital anomalies of the optic disc are fortunately rare, and in many cases either unilateral or asymmetrical involvement means that functional vision is not significantly impaired. However, children with poor vision due to these conditions are not uncommonly seen in paediatric practice and accurate diagnosis and good management are essential.
GN Dutton

Excavations of the optic disc

Optic disc coloboma

Definition

Optic disc coloboma (Figure 1) comprises a clearly demarcated bowl-shaped excavation of the optic disc, which is typically decentred and deeper inferiorly.

\section{Aetiology}

Coloboma of the optic disc is thought to result from abnormal fusion of the two sides of the proximal end of the optic cup. ${ }^{1}$ The condition can occur in association with multiple congenital abnormalities indicative of an insult to the developing foetus during the sixth week of gestation. ${ }^{2}$

Optic nerve coloboma may occur sporadically or be inherited with an autosomal dominant inheritance. ${ }^{3}$ It has recently been shown to be associated with PAX2 gene mutations as part of the renal-coloboma syndrome. ${ }^{4-7}$ Expression of PAX2 is restricted to cells of astrocytic lineage both during retinal development and in adulthood. Using immunohistochemistry, it has been found that adult retinal cells with the

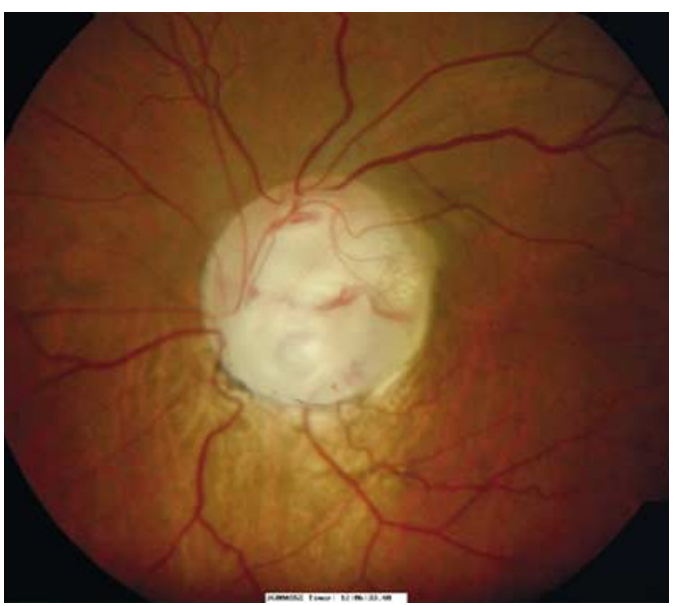

Figure 1 Coloboma of the optic nerve head. 
antigenic phenotype present in mature perinatal astrocytes are found only in the region surrounding the optic nerve head, and that astrocyte precursor cells expressing PAX2 are found in a small region surrounding the optic nerve during early development. It has been argued that these findings suggest that coloboma formation may be associated with impaired astrocyte differentiation during development. ${ }^{8}$

The association of optic nerve coloboma with dysgenesis of the internal carotid artery and transphenoidal encephalocele with hypopituitarism has led to the suggestion that the link between these malformations is abnormal neural crest cell development. ${ }^{9}$

\section{Clinical features}

Unilateral and bilateral optic disc colobomata occur with similar frequencies. ${ }^{10}$ The coloboma occupies the lower part of the optic nerve head. The neuro-retinal rim is absent inferiorly but is usually identifiable superiorly. In cases in which the adjacent inferior retina and choroid are deficient, microphthalmia may also be evident. ${ }^{11}$

Visual acuity is reduced to varying degrees. Careful analysis of the photographic appearances of colobomata involving the optic nerve has shown that the only feature that relates to visual outcome is the degree of foveal involvement by the coloboma. ${ }^{12}$ The size of the coloboma, the colour of the optic nerve, and the presence of subfoveal pigment change are not related to visual outcome. Significant refractive error and anisometropia are common. ${ }^{12}$

Progressive optic nerve cupping and neural rim decrease have been documented in a patient with bilateral autosomal dominant optic nerve colobomas with no evidence of raised intraocular pressure and remarkably, no progressive visual field loss. ${ }^{13}$

Circumferential intrascleral smooth muscle has been observed histologically ${ }^{14}$ and may account for the rare observation of spontaneous contractility of the colobomatous optic disc. ${ }^{15}$

\section{Complications}

A small proportion of cases are associated with cysts arising from the optic nerve sheath, which communicate with the subarachnoid space. ${ }^{16}$ Rarely such cysts can enlarge and lead to compressive optic neuropathy. ${ }^{17}$

Peripapillary choroidal neovascularisation has been described in association with optic nerve coloboma. ${ }^{18}$ Retinal detachment is also a recognised complication, and remarkably, spontaneous re-attachment may occur. ${ }^{19-21}$ The source of the subretinal fluid is not known but could derive from fluid entering the retrobulbar space from surrounding orbital tissue, or from the choriocapillaris, or from CSF. In contrast to retinochoroidal colobomas, rhegmatogenous detachment is probably not a recognised association. ${ }^{11}$

Contrary to what is commonly taught, basal encephalocele is a rare association with optic nerve coloboma $^{11}$ (in contrast to the more common association with morning glory syndrome).

\section{Associations}

There is a wide range of associations. These have been reviewed by Brodsky ${ }^{11}$ and include the CHARGE association (coloboma, choanal atresia, congenital heart disease, and multiple other abnormalities), WalkerWarburg syndrome, Goltz focal dermal hypoplasia, Aicardi syndrome, Goldenhar syndrome, and linear sebaceous naevus syndrome. More recently, associations with Dandy Walker malformation ${ }^{22}$ and renal coloboma syndrome (with a mutation of PAX2 transcription) ${ }^{4-7}$ have also been described.

\section{Treatment}

A trial of patching may result in improvement of vision in the child presenting early in life, and optimal refractive correction may be indicated.

\section{Morning glory anomaly}

\section{Definition}

The morning glory optic disc (Figure 2) anomaly is a congenital optic disc dysplasia in which a conical excavation of the posterior fundus includes the optic disc and is filled with glial tissue. The term reflects the morphological similarity to the flower of the morning glory plant. $^{23}$

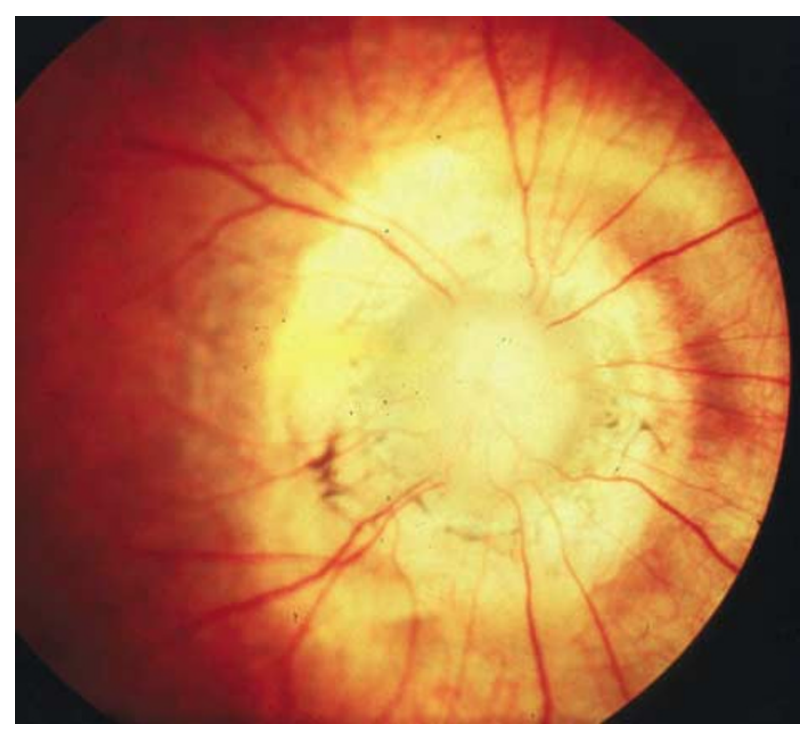

Figure 2 Morning glory syndrome (reproduced with permission from the British Journal of Ophthalmic Photography). 
Aetiology

Morning glory syndrome is ostensibly a sporadic condition but it has been described occurring in isolation in a parent and child. ${ }^{24}$

The pathogenesis of the condition is unknown. ${ }^{11}$ One hypothesis argues that the condition results from failure of closure of the foetal fissure and that it is a variant of optic nerve coloboma. Alternatively, a primary mesenchymal abnormality has been postulated on the basis of the glial tuft, the scleral and vascular abnormalities, and the finding of adipose and smooth muscle tissue around the terminal optic nerve. An alternative argument is that the symmetrical excavation of the optic nerve head, which characterises the disorder, is suggestive of dilation due to dysgenesis of the terminal optic stalk, which fails to close, leading to persistent excavation of the optic nerve head. The central gliosis and the vascular pattern suggest primary neuroectodermal dysgenesis. ${ }^{10}$

Morning glory syndrome is more common in female population and (in the USA) occurs less commonly in black people. $^{10}$

\section{Clinical features}

Morning glory syndrome is usually unilateral and is characterised by a funnel-shaped, excavated optic disc (which may even include the macula) with central glial tissue surrounded by chorioretinal pigmentary disturbance. The central glial material may be either elevated or recessed. ${ }^{10,11}$ The retinal vessels are increased in number and appear to arise from the disc margin from where they tend to run to the peripheral retina in a straighter course than usual. Fluorescein angiography has revealed arteriovenous communications near the optic disc. ${ }^{25}$

The visual acuity is usually reduced, being in the region of count fingers to $6 / 60$, but it can be associated with no perception of light. Rarely the acuity can be as good as $6 / 6$.

The remarkable phenomenon of contractile movements of the optic disc has been reported on a number of occasions. In one reported case, phasic contraction was observed by scanning laser ophthalmoscopy over 2-s periods of contraction and 20 -s periods of recovery. The contractile movement was not related to exposure to strong light or the Valsalva manoeuvre but it seemed to be induced by massage of the eyeball. ${ }^{26}$ In another reported case, both the contractions and the periods of relaxation lasted for 4-s, occurring between three and five times a minute. ${ }^{27}$ Histologically, a cuff of smooth muscle tissue has been identified within the terminal optic nerve and this may account for the observed movement. $^{28,29}$

\section{Associations and complications}

Morning glory syndrome tends to be an isolated condition and does not occur as part of a multisystem disorder. It can however be associated with transphenoidal encephalocele and hypopituitarism. ${ }^{30,31}$ Patients with this condition tend to have a wide head and hypertelorism associated with a flattened nasal bridge. The encephalocele bulges into the nasopharynx where it can obstruct respiration. Incorrect identification and management of this pathology as a nasal polyp has been reported to lead to a fatal outcome. ${ }^{32}$

Rhegmatogenous retinal detachment (which can now be successfully treated) can be associated with a break at the optic disc margin ${ }^{33}$ or within the optic disc cup, ${ }^{34}$ and may occur in about one-third of cases. ${ }^{11}$ Remarkably, optic nerve fenestration has been reported to lead to resolution of serous retinal detachment, suggesting that the source of subretinal fluid can be CSF. ${ }^{35}$ Spontaneous resolution of retinal detachment has also been reported. ${ }^{36}$

Subretinal neovascularisation both under the peripapillary retina ${ }^{37}$ and under the fovea ${ }^{38}$ is a recognised complication.

\section{Treatment}

When the condition is first seen in young children, a trial of occlusion is warranted but should not be continued if improvement in vision does not take place.

\section{Peripapillary staphyloma}

\section{Definition}

Peripapillary staphyloma consists of a deep excavation of the area of the fundus surrounding the optic disc

(Figure 3).

\section{Epidemiology}

The condition is sporadic, very rare, usually unilateral, and is not inherited.

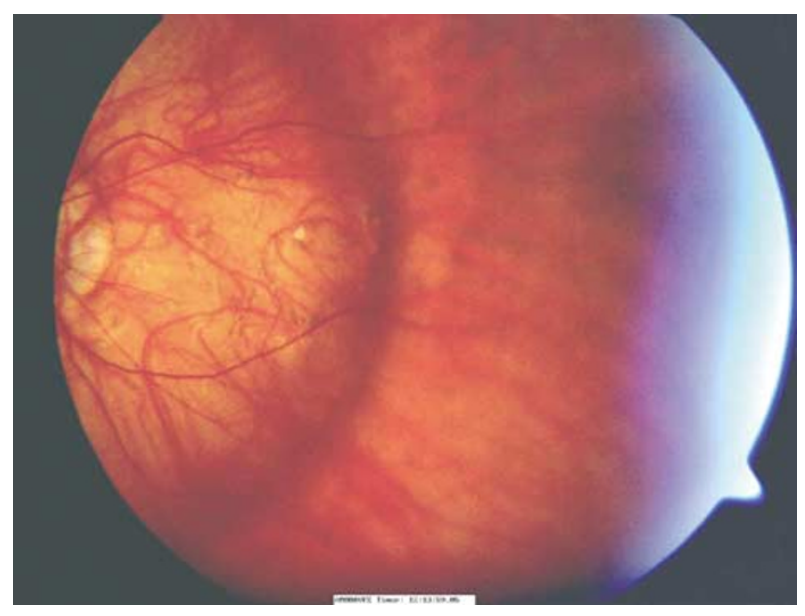

Figure 3 Peripapillary staphyloma. 


\section{Aetiology}

The aetiology is unknown. It appears to arise as a sequel to disturbance of scleral development at about 20 weeks gestation, perhaps arising as a consequence of the new development of intraocular pressure causing scleral herniation at this stage of development. ${ }^{10}$

\section{Clinical features}

The optic nerve may look normal or manifest temporal pallor but it is situated within an excavated defect of the sclera lined by retina and choroid, which tend to be atrophic in appearance. Like optic nerve coloboma and morning glory syndrome, spontaneous contractility and relaxation of the staphyloma has been observed. ${ }^{39,40}$

Vision is usually markedly reduced in the affected eye but has occasionally been reported as near normal. ${ }^{39} \mathrm{~A}$ centrocaecal scotoma may be present in eyes with reduced visual acuity. Myopia or emmetropia most commonly accompanies the condition.

\section{Associations}

In most reported cases, peripapillary staphyloma occurs in isolation and is unilateral. ${ }^{41}$ Two out of six patients with frontonasal dysplasia in association with basal encephalocele were found to have either unilateral or bilateral peripapillary staphyloma. ${ }^{42}$ Both facial capillary haemangioma ${ }^{43}$ and linear nevus sebaceous syndrome are rare associations. ${ }^{44}$

\section{Optic nerve hypoplasia}

\section{Definition}

Optic nerve hypoplasia $(\mathrm{ONH})$ is seen ophthalmoscopically as an abnormally small optic nerve head. Recently, the definition has been extended to include cases of optic nerve head cupping, which accompany periventricular leucomalacia (PVL). In both conditions, there are fewer fibres in the optic nerve from the time of birth.

\section{Epidemiology}

$\mathrm{ONH}$ is among the three leading causes of blindness in children in the United states. The other causes are cerebral damage and retinopathy of prematurity. ${ }^{45}$

\section{Aetiology}

In most cases, $\mathrm{ONH}$ is a sporadic occurrence for which there is no identifiable cause. There are, however, a number of associations, which are listed in Table 1 . Supranormal regression of axons in the optic nerve

Table 1 Disorders associated with $\mathrm{ONH}$ (conditions listed in an alphabetical order)

\begin{tabular}{|c|c|c|}
\hline Condition & Comment & Reference \\
\hline Aicardi syndrome & Case report & 106 \\
\hline Anticonvulsants in pregnancy & Seven cases & 107 \\
\hline CHARGE association & Found in four out of 50 patients & 108 \\
\hline Distal $5 q$ deletion syndrome & Multiple abnormalities present & 109 \\
\hline Dominant inheritance & Five individuals in four generations & 67 \\
\hline Duane's retraction syndrome & Isolated association & 110 \\
\hline $\begin{array}{l}\text { Partial deletion of } \\
\text { chromosome } 6 \mathrm{p}\end{array}$ & Multiple abnormalities present & 111 \\
\hline \multirow[t]{2}{*}{$\begin{array}{l}\text { Chromosome } 7(\mathrm{q} 22 \rightarrow \mathrm{q} 34) \text { and } 7(\mathrm{q} 32-34) \\
\text { interstitial duplication }\end{array}$} & Multiple abnormalities present & 112 \\
\hline & & 113 \\
\hline Chromosome 17 interstitial deletion & Multiple abnormalities present & 71 \\
\hline \multirow[t]{2}{*}{ Ethanol toxicity } & $\begin{array}{l}\text { Causes selective loss of small-diameter myelinated optic nerve } \\
\text { axons (in animal models) }\end{array}$ & 114 \\
\hline & & 51 \\
\hline Frontonasal dysplasia & Seen in seven of 23 patients with dysplasia & 115 \\
\hline Goldenhar-Gorlin syndrome & Hypoplasia and optic nerve agenesis described & 116 \\
\hline Idiopathic growth hormone deficiency & MRI study, pituitary gland defects common. ONH in $9 \%$ & 117 \\
\hline Isotretinoin toxicity & Taken during pregnancy & 118 \\
\hline Nevus sebaceous of Jadassohn & Cutaneous phacomatosis with malignant potential & 119 \\
\hline Maternal diabetes mellitus & $\begin{array}{l}\mathrm{ONH} \text { is an isolated defect associated in general with good } \\
\text { visual acuity }\end{array}$ & 120 \\
\hline Muscle eye brain disease & Autosomal recessive condition Chromosome 1p anomaly & 121 \\
\hline Orbital haemangioma & Association of orbital haemangioma lens coloboma, and $\mathrm{ONH}$ & 122 \\
\hline Periventricular leucomalacia & $\begin{array}{l}\text { Typical ONH or marked cupping of the optic discs can be seen. } \\
\text { May be due to retrograde transynaptic degeneration }\end{array}$ & 58,59 \\
\hline Suprasellar teratoma & Case report & 123 \\
\hline Valproic acid toxicity & SOD and other features & 124 \\
\hline
\end{tabular}


(rather than a primary failure of differentiation) is thought to be the principal mechanism of development of $\mathrm{ONH}^{46}{ }^{46}$ Histopathologically, the lack of degenerated neurons in $\mathrm{ONH}$ is indicative of axonal loss due to apoptosis during development. ${ }^{47}$

Risk factors for $\mathrm{ONH}$ include young maternal age, first parity, maternal smoking, and preterm birth and its complications. ${ }^{48} \mathrm{ONH}$ is a known feature of foetal alcohol syndrome in both $\operatorname{man}^{49-51}$ and experimental animal models. ${ }^{52,53}$ Superior segmental ONH has been found in three of 34 children born to mothers with type I diabetes. $^{54}$

$\mathrm{ONH}$ can occur in association with lesions at any site in the developing visual system ${ }^{55,56}$ particularly in subcortical (rather than cortical) damage. ${ }^{57}$ Loss of periventricular white matter due to PVL is commonly associated with optic disc anomalies. ${ }^{58,59}$ As a rule, PVL of early onset is associated with small optic discs, whereas PVL of later onset is more likely to be associated with optic disc cupping. It has been hypothesised that retrograde trans-synaptic degeneration occurs when the periventricular visual pathways have been damaged, and that the pattern of optic nerve pathology that results depends on the timing of the damage. ${ }^{58,59}$

In a small but significant proportion of patients with ONH (both with and without associated brain abnormalities), either subnormal or negative like electroretinograms have been recorded. It has been argued that these findings may indicate that in a subset of cases with $\mathrm{ONH}$ and nystagmus, the retinal pathology may have been primary ${ }^{60}$ or that trans-synaptic degeneration beyond the ganglion cell layer may take place. $^{61}$

Septo-optic dysplasia (SOD) is now considered to comprise any combination of $\mathrm{ONH}$, pituitary gland hypoplasia, and midline abnormalities of the brain. Recent studies have shown that in SOD, key mutations have been identified in Hesx-1, a protein that is involved in the mediation of normal development of the forebrain and the eyes during embryogenesis. ${ }^{62}$

In the embryonic mouse, optic nerve formation involves interaction between netrin-1, which is an axon guidance molecule on neuroepithelial cells at the optic disc, and the receptor for netrin-1 found on retinal ganglion cell axons. Deficiency of either of these proteins leads to deficits in retinal ganglion cell pathfinding, resulting in $\mathrm{ONH}$ and deficits in hypothalamic development. ${ }^{63,64}$

ONH has only rarely been reported in siblings, ${ }^{65}$ identical twins, ${ }^{66}$ or running in a family. ${ }^{67}$

\section{Clinical features}

A peripapillary ring around a small optic disc is the hallmark of $\mathrm{ONH}$, but is not always present. ${ }^{68}$
Biomicroscopy may reveal a pathological thinness of the nerve fibre layer. ${ }^{69} \mathrm{ONH}$ may be associated with tortuosity of the retinal vasculature. ${ }^{70}$ This feature has in one study also been shown to be associated with the development of endocrinopathy. ${ }^{70}$ A persistent grey appearance has also been described. ${ }^{71}$

The ratio of the distance between the centre of the optic disc to the centre of the macula (DM) and the mean optic disc diameter (DD) (ie the DM to DD ratio) provides an index of the size of the optic disc on clinical examination and on photography ${ }^{72,73}$ (Figure 4). In one study, a ratio of 2.94 provided a one-tailed upper population limit of $95 \% .^{74}$ For practical purposes, a DM:DD ratio of 3.00 should lead to serious consideration of the diagnosis ${ }^{73}$ and a value of 4.00 probably accords a definitive diagnosis. ${ }^{75}$ The visual acuity is associated with the $\mathrm{DM}$ : DD ratio. In one study of 19 children with $\mathrm{ONH}$, all eyes with a DM:DD ratio of more than 3 had reduced visual acuities but all those with a ratio of less than 3 had normal acuities. ${ }^{76}$ In another study, however, in $75 \%$ of bilateral cases, the eye with the relatively smaller optic disc was paradoxically found to have a better visual acuity than the fellow eye. ${ }^{74}$ Both the degree of afferent pupillary dysfunction ${ }^{76}$ and reduction in brightness sense $^{77}$ are also related to the level of acuity.

When the condition is asymmetrical, a relative afferent pupil defect adds weight to the diagnosis. ${ }^{69}$ As one would expect, abnormality of the visual evoked potential is typically observed but the photopic and scotopic ERG tend to be normal. ${ }^{78}$

$\mathrm{ONH}$ is commonly asymptomatic and may first be detected by identification of visual field loss or observation of the optic nerve head. Segmental ONH,

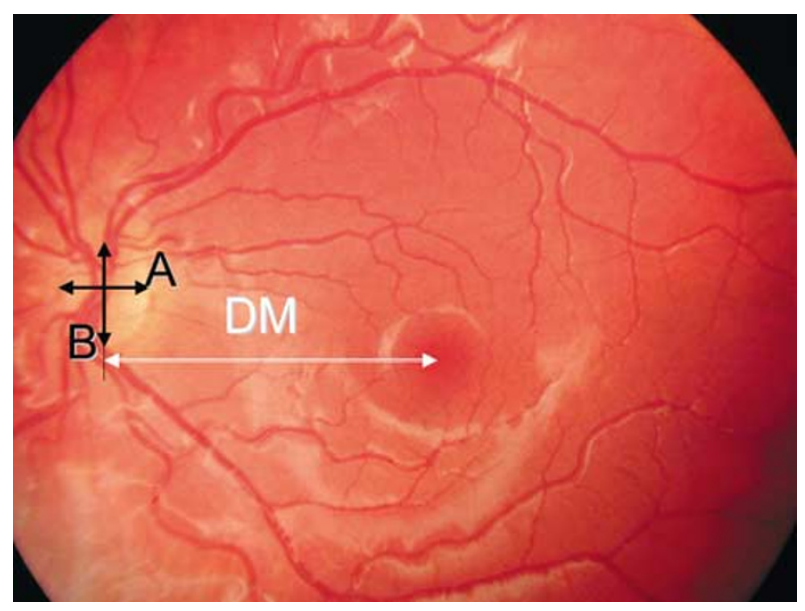

Figure $4 \mathrm{ONH}$. The mean disc diameter (DD) is $(\mathrm{A}+\mathrm{B})-2$. The perpendicular distance between the centre of the disc and the macula is shown as DM (the distance between the centre of the disc and the centre of the macula). When the ratio of DM to $\mathrm{DD}$ is greater than $3, \mathrm{ONH}$ is suspected, and when it is greater than $4, \mathrm{ONH}$ is very likely. 
which is commonly superior (causing a lower visual field defect) ${ }^{79}$ can be identified by clinical observation, red free photography, ${ }^{80}$ or by optical coherence tomography. ${ }^{81}$

Reduced optic nerve diameter (from the normal range of $4-4.5 \mathrm{~mm}$ ) measured by ultrasound has been described, and the diameter of the optic canal may be reduced. ${ }^{82}$ In addition to demonstrating associated intracranial disorders, magnetic resonance imaging of the intracranial visual pathways may demonstrate reduced size of the optic nerves ${ }^{83}$ and diffuse chiasmal hypoplasia, which can lend considerable weight to the diagnosis of $\mathrm{ONH} .^{84}$

\section{Associations}

Magnetic resonance imaging has revealed coexistent CNS abnormalities in 30 out of 40 patients with ONH. ${ }^{85}$ These authors describe a number of different features.

\section{Isolated $\mathrm{ONH}$.}

2. Absent septum pellucidum. (This anomaly has not been found to be associated with significant intellectual, behavioural, or neurological dysfunction. ${ }^{86}$ )

3. Posterior pituitary ectopia (commonly associated with endocrine dysfunction).

4. Migrational anomalies in the cerebral hemispheres (for example, thinning of the corpus callosum, which is predictive of neurodevelopmental problems).

Other associated brain abnormalities include porencephaly, schizencephaly, intracranial arachnoid cyst, and intracranial epidermoid cyst. ${ }^{56,87,88}$

We have seen a number of infants presenting with neonatal hypoglycaemia who have later been shown to have SOD with pituitary insufficiency. $\mathrm{ONH}$ with an absent septum pellucidum has the highest incidence of multiple pituitary endocrinopathies ${ }^{89}$ and of neonatal hypoglycaemia, ${ }^{90}$ which may be associated with neonatal cholestatic jaundice. ${ }^{91}$ Growth hormone deficiency, adrenocorticotrophic hormone deficiency, thyroidstimulating hormone deficiency, and diabetes insipidus have all been described. ${ }^{92}$ Identification of hypopituitarism to identify low cortisol is essential. Coma and convulsions due to hypoglycaemia have followed uncomplicated surgery under general anaesthetic. ${ }^{93}$ Even adult death from associated adrenal hypoplasia has been described. ${ }^{94}$ Preservation of secretion of gonadotrophins, however, is not uncommon. ${ }^{95}$ Hypoplasia of the olfactory tract can be associated. $^{96}$

Children with bilateral $\mathrm{ONH}$ affecting the whole of each optic nerve, and those with poor vision and nystagmus, are more likely to have non-ocular developmental abnormalities than those with unilateral or bilateral segmental hypoplasia. ${ }^{97}$

\section{Treatment}

In some cases patching can improve vision, but in others patching makes no difference. ${ }^{98}$ If patching is not successful in improving visual function, it should be stopped to prevent distress. Careful refraction and prescription of spectacles is indicated in selected cases to prevent an additional amblyopic component from astigmatism, which has been found to be commoner in children with $\mathrm{ONH} .{ }^{99}$

\section{Prognosis}

Some children with bilateral $\mathrm{ONH}$, who present as blind in early infancy, may show a degree of delayed visual maturation and go on to develop mobility vision or better during the ensuing 2 years. ${ }^{100}$

\section{Optic disc cupping in PVL - a variant of ONH?}

PVL has recently emerged as an important and common cause of visual impairment in children. ${ }^{101}$ Disturbance of development of posterior periventricular white matter at a time of intrauterine development between 29 and 34 weeks can give rise to reduced acuity with features of crowding, lower visual field impairment, and a range of cognitive disorders in visual function. In a significant proportion of patients, optic disc cupping with thinning of the neuro-retinal rim has been observed. ${ }^{58}$

Trans-synaptic degeneration probably accounts for the cupping. It is known for example that damage to the occipital lobes in young monkeys gives rise to loss of ganglion cells in the retina. ${ }^{102,103}$ Such damage in the adult monkey leads to the same phenomenon, but to a much lesser degree. ${ }^{104}$

Jacobson et al ${ }^{58}$ describe $\mathrm{ONH}$ in association with PVL of probable early onset, but optic disc cupping in cases in which the disorder probably occurred at a later stage. In cases in which the pattern of PVL is suggestive of pathology at an earlier stage of development (affecting frontal periventricular white matter) ONH was observed, whereas in cases of presumed later onset (subcortical posterior PVL) optic disc cupping was observed. These authors therefore propose that early-onset pathology results in contraction of the size of the optic nerve (resulting in a classical pattern of $\mathrm{ONH}$ ) but that such pathology of later onset leads to a cupped optic disc, which they argue is a variant of $\mathrm{ONH}$; the pattern of the latter is due to the lesser plasticity of the sclera to adapt to the neuronal loss at a later stage of development. 
Management of the child with visual impairment due to disorders of the optic nerve

Bilateral disorders of the structure of the optic nerve commonly result in impaired functional vision presenting in early childhood. It is essential that the child and his/her family are well looked after from the outset.

\section{Optimising visual function}

Refractive error is common. Astigmatism needs to be corrected for eyes in which there is evidence of visual function. In our experience, dynamic retinoscopy commonly reveals impaired accommodation, and the correction of relatively small amounts of hypermetropia can be rewarded with significant visual improvement in some cases.

There may be super-added amblyopia. A short trial of patching of the eye with the worse visual function is warranted, but if there is no improvement this should not be continued.

\section{Working with parents}

Breaking the news that vision is impaired requires compassion and sensitivity. The first consultation rarely conveys much information, and a planned approach at a later stage to discussing the wide range of questions that arise is essential. Parents need accurate and clear information about the condition and its prognosis. Such information is currently available on the internet, but only dedicated sites warrant recommendation (see Appendix A). Parents also need advice concerning how to look after a visually impaired child. For infants, the developmental guide 'Show Me what My Friends Can See ${ }^{\prime 105}$ can prove very helpful. Genetic counselling is indicated when there is a clear family history.

\section{Measuring visual function and working within visual limitations}

Vision is required for communication, access to information, and mobility. The maximum distance at which faces can be seen, and facial expressions seen and learned from, needs to be determined and conveyed to parents and carers. The language framework required to compensate for reduced vision should be established. The size and contrast, and the proximity of toys and printed information required for maximum speed of access to the information need to be determined. The provision of low-vision aids at an early stage warrants consideration. The visual limitations to all aspects of mobility need to be understood and compensated for.
Ensuring that impaired vision does not lead to developmental delay

Early intervention can contribute significantly to a positive developmental outcome. This needs to be put in place at an early stage by notifying and informing the appropriate authorities.

Sources of information for parents and children

Reliable sources of information are very much appreciated by families. United Kingdom sources are listed in Appendix A.

In conclusion, in the majority of cases, disorders of optic nerve structure are sporadic and the aetiology is unknown. A positive approach aimed at habilitation and optimising visual function from an early stage during development reaps dividends. An approach that says 'there is nothing more I can do' should be a thing of the past!

\section{References}

1 Mann I. Developmental Abnormalities of the Eye, 2nd ed. JB Lippincott: Philadelphia, PA, 1957, pp 74--91.

2 Duvall J, Miller SL, Cheatle E, Tso MO. Histopathologic study of ocular changes in a syndrome of multiple congenital anomalies. Am J Ophthalmol 1987; 103: 701-705.

3 Yamashita T, Kawano K, Ohba N. Autosomal dominantly inherited optic nerve coloboma. Ophthalmic Paediatr Genet 1988; 9: 17-24.

4 Oppezzo C, Barberis V, Edefonti A, Cusi D, Marra G. Congenital anomalies of the kidney and urinary tract. $G$ Ital Nefrol 2003; 20: 120-126.

5 Chung GW, Edwards AO, Schimmenti LA, Manligas GS, Zhang YH, Ritter III R. Renal-coloboma syndrome: report of a novel PAX2 gene mutation. Am J Ophthalmol 2001; 132: 910-914.

6 Salomon R, Tellier AL, Attie-Bitach T, Amiel J, Vekemans M, Lyonnet $\mathrm{S}$ et al. PAX2 mutations in oligomeganephronia. Kidney Int 2001; 59: 457-462.

7 Eccles MR, Schimmenti LA. Renal-coloboma syndrome: a multi-system developmental disorder caused by PAX2 mutations. Clin Genet 1999; 56: 1-9.

8 Chu Y, Hughes S, Chan-Ling T. Differentiation and migration of astrocyte precursor cells and astrocytes in human fetal retina: relevance to optic nerve coloboma. FASEB J 2001; 15: 2013-2015.

9 Blustajn J, Netchine I, Fredy D, Bakouche P, Piekarski JD, Meder JF. Dysgenesis of the internal carotid artery associated with transsphenoidal encephalocele: a neural crest syndrome? Am J Neuroradiol 1999; 20: 1154-1157.

10 Pollock S. The morning glory disc anomaly: contractile movement, classification and embryogenesis. Doc Ophthalmol 1987; 65: 439-460.

11 Brodsky MC. Congenital anomalies of the optic disc. In: Miller NR, Newman NG (eds). Walsh \& Hoyt's Clinical Neuro-ophthalmology, 5th ed, Chapter 18 Williams \& Wilkins: Baltimore, MO, 1998, pp 775-823.

12 Olsen TW, Summers CG, Knobloch WH. Predicting visual acuity in children with colobomas involving the optic nerve. J Pediatr Ophthalmol Strabismus 1996; 33: 47-51. 
13 Moore M, Salles D, Jampol LM. Progressive optic nerve cupping and neural rim decrease in a patient with bilateral autosomal dominant optic nerve colobomas. Am J Ophthalmol 2000; 129: 517-520.

14 Font RL, Zimmerman LE. Intrascleral smooth muscle in coloboma of the optic disc. Am J Ophthalmol 1971; 72 452-457.

15 Foster JA, Lam S. Contractile optic disc coloboma. Arch Ophthalmol 1991; 109: 472-473.

16 Wiggins RE, von Noorden GK, Boniuk M. Optic nerve coloboma with cyst: a case report and review. J Pediatr Ophthalmol Strabismus 1991; 28: 274-277.

17 Rosenberg LF, Burde RM. Progressive visual loss caused by an arachnoidal brain cyst in a patient with an optic nerve coloboma. Am J Ophthalmol 1988; 106: 322-325.

18 Dailey JR, Cantore WA, Gardner TW. Peripapillary choroidal neovascular membrane associated with an optic nerve coloboma. Arch Ophthalmol 1993; 111: 441-442.

19 Shami M, McCartney D, Benedict W, Barnes C. Spontaneous retinal reattachment in a patient with persistent hyperplastic primary vitreous and an optic nerve coloboma. Am J Ophthalmol 1992; 114: 769-771.

20 Bochow TW, Olk RJ, Knupp JA, Smith ME. Spontaneous reattachment of a total retinal detachment in an infant with microphthalmos and an optic nerve coloboma. Am J Ophthalmol 1991; 112: 347-348.

21 Lin CC, Tso MO, Vygantas CM. Coloboma of optic nerve associated with serous maculopathy. A clinicopathologic correlative study. Arch Ophthalmol 1984; 102: 1651-1654.

22 Toriello HV, Lemire EG. Optic nerve coloboma, Dandy-Walker malformation, microglossia, tongue hamartomata, cleft palate and apneic spells: an existing oral-facial-digital syndrome or a new variant? Clin Dysmorphol 2002; 11: 19-23.

23 Kindler P. Morning glory syndrome: unusual congenital optic disk anomaly. Am J Ophthalmol 1970; 69: 376-384.

24 Nagy V, Kettesy B, Toth K, Vamosi P, Damjanovich J, Berta A. Morning glory syndrome - a clinical study of two cases. Klin Monatsbl Augenheilkd 2002; 219: 801-805.

25 Brodsky MC, Wilson RS. Retinal arteriovenous communications in the morning glory disc anomaly. Arch Ophthalmol 1995; 113: 410-411.

26 Chuman H, Nao-i N, Sawada A. A case of morning glory syndrome associated with contractile movement of the optic disc and subretinal neovascularization. Nippon Ganka Gakkai Zasshi 1996; 100: 705-709.

27 Verity D, Pyott A, Lee WR. Morning glory syndrome and a mobile posterior segment. Br J Ophthal Photography 1999; 2: 30-31.

28 Dempster AG, Lee WR, Forrester JV, McCreath GT. The morning glory syndrome. A mesodermal defect? Ophthalmolooica (Basel) 1983; 187: 222-230.

29 Willis R, Zimmerman LE, O'Grady R, Smith RS, Crawford B. Heterotopic adipose tissue and smooth muscle in the optic disc. Arch Ophthalmol 1972; 88: 139-146.

30 Eustis HS, Sanders MR, Zimmerman T. Morning glory syndrome in children. Association with endocrine and central nervous system anomalies. Arch Ophthalmol 1994; 112: 204-207.

31 Komiyama M, Yasui T, Sakamoto H, Fujita K, Sato T, Ota M et al. Basal meningoencephalocele, anomaly of optic disc and panhypopituitarism in association with moyamoya disease. Pediatr Neurosurg 2000; 33: 100-104.
32 Pollock JA, Newton TH, Hoyt WF. Transphenoidal and transethmoidal encephaloceles: a review of clinical and roentgen features in 8 cases. Radiology 1968; 90: 442-453.

33 Ho CL, Wei LC. Rhegmatogenous retinal detachment in morning glory syndrome pathogenesis and treatment. Int Ophthalmol 2001; 24: 21-24.

34 Coll GE, Chang S, Flynn TE, Brown GC. Communication between the subretinal space and the vitreous cavity in the morning glory syndrome. Graefes Arch Clin Exp Ophthalmol 1995; 233: 441-443.

35 Chang S, Haik BG, Ellsworth RM, St Louis, L. Treatment of total retinal detachment in morning glory syndrome. Am J Ophthalmol 1984; 97: 596-600.

36 Haik BG, Greenstein SH, Smith ME, Abramson DH, Ellsworth RM. Retinal detachment in the morning glory syndrome. Ophthalmology 1984; 91: 1638-1647.

37 Sobol WM, Bratton AR, Rivers MB, Weingeist TA. Morning glory disc syndrome associated with subretinal neovascularisation. Am J Ophthalmol 1990; 110: 93-94.

38 Chuman H, Nao-i N, Sawada A. A case of morning glory syndrome associated with contractile movement of the optic disc and subretinal neovascularization. Nippon Ganka Gakkai Zasshi 1996; 100: 705-709.

39 Konstas P, Katikos G, Vatakas LC. Contractile peripapillary staphyloma. Ophthalmologica 1976; 172: 379-381.

40 Farah ME, Uno F, Bonomo PP, Nobrega M, Hofling-Lima AL. Contractile peripapillary staphyloma with light stimulus to the contralateral eye. Arch Ophthalmol 2001; 119: 1216-1217.

41 Gottlieb JL, Prieto DM, Vander JF, Brown GC, Tasman WS. Peripapillary staphyloma. Am J Ophthalmol 1997; 124: 249-251.

42 Hodgkins P, Lees M, Lawson J, Reardon W, Leitch J, Thorogood $\mathrm{P}$ et al. Optic disc anomalies and frontonasal dysplasia. Br J Ophthalmol 1998; 82: 290-293.

43 Kiratli H, Bozkurt B, Mocan C. Peripapillary staphyloma associated with orofacial capillary hemangioma. Ophthalmic Genet 2001; 22: 249-253.

44 Brodsky MC, Kincannon JM, Nelson-Adesokan P, Brown $\mathrm{HH}$. Oculocerebral dysgenesis in the linear nevus sebaceous syndrome. Ophthalmology 1997; 104: 497-503.

45 Steinkuller PG, Du L, Gilbert C, Foster A, Collins ML, Coats DK. Childhood blindness. J AAPOS 1999; 3: 26-32.

46 Lambert SR, Hoyt CS, Narahara MH. Optic nerve hypoplasia. Surv Ophthalmol 1987; 32: 1-9.

47 Saadati HG, Hsu HY, Heller KB, Sadun AA. A histopathologic and morphometric differentiation of nerves in optic nerve hypoplasia and Leber's hereditary optic neuropathy. Arch Ophthalmol 1998; 116: 911-916.

48 Tornqvist K, Ericsson A, Kallen B. Optic nerve hypoplasia: risk factors and epidemiology. Acta Ophthalmol Scand 2002; 80: 300-304.

49 Stromland K, Hellstrom A. Fetal alcohol syndrome - an ophthalmological and socioeducational prospective study. Pediatrics 1996; 97: 845-850.

50 Stromland K, Sundelin K. Paediatric and ophthalmologic observations in offspring of alcohol abusing mothers. Acta Paediatr 1996; 85: 1463-1468.

51 Stromland K, Pinazo-Duran MD. Ophthalmic involvement in the fetal alcohol syndrome: clinical and animal model studies. Alcohol 2002; 37: 2-8.

52 Parson SH, Dhillon B, Findlater GS, Kaufman MH. Optic nerve hypoplasia in the fetal alcohol syndrome: a mouse model. J Anat 1995; 186: 313-320. 
53 Stromland K, Pinazo-Duran MD. Optic nerve hypoplasia: comparative effects in children and rats exposed to alcohol during pregnancy. Teratology 1994; 50: 100-111.

54 Landau K, Bajka JD, Kirchschlager BM. Topless optic disks in children of mothers with type I diabetes mellitus. Am J Ophthalmol 1998; 125: 605-611.

55 Novakovic P, Taylor DS, Hoyt WF. Localising patterns of optic nerve hypoplasia - retina to occipital lobe. $\mathrm{Br} J$ Ophthalmol 1988; 72: 176-182.

56 Zeki SM, Hollman AS, Dutton GN. Neuroradiological features of patients with optic nerve hypoplasia. J Pediatr Ophthalmol Strabismus 1992; 29: 107-112.

57 Brodsky MC, Fray KJ, Glasier CM. Perinatal cortical and subcortical visual loss: mechanisms of injury and associated ophthalmologic signs. Ophthalmology 2002; 109 85-94.

58 Jacobson L, Hellstrom A, Flodmark O. Large cups in normal-sized optic discs: a variant of optic nerve hypoplasia in children with periventricular leukomalacia. Arch Ophthalmol 1997; 115: 1263-1269.

59 Jacobson L, Ygge J, Flodmark O. Nystagmus in periventricular leucomalacia. Br J Ophthalmol 1998; 82: 1026-1032.

60 Janaky M, Deak A, Pelle Z, Benedek G. Electrophysiologic alterations in patients with optic nerve hypoplasia. Doc Ophthalmol 1994; 86: 247-257.

61 Cibis GW, Fitzgerald KM. Optic nerve hypoplasia in association with brain anomalies and an abnormal electroretinogram. Doc Ophthalmol 1994; 86: 11-22.

62 de la Mata I, Garcia JL, Gonzalez C, Menendez M, Canada $\mathrm{J}$, Jimenez-Barbero J et al. The impact of R53C mutation on the three-dimensional structure, stability, and DNA-binding properties of the human Hesx-1 homeodomain. Chembiochem 2002; 3: 726-740.

63 Deiner MS, Kennedy TE, Fazeli A, Serafini T, Tessier-Lavigne M, Sretavan DW. Netrin-1 and DCC mediate axon guidance locally at the optic disc: loss of function leads to optic nerve hypoplasia. Neuron 1997; 19: 575-589.

64 Deiner MS, Sretavan DW. Altered midline axon pathways and ectopic neurons in the developing hypothalamus of netrin-1- and DCC-deficient mice. J Neurosci 1999; 19: 9900-9912.

65 Benner JD, Preslan MW, Gratz E, Joslyn J, Schwartz M, Kelman S. Septo-optic dysplasia in two siblings. Am J Ophthalmol 1990; 109: 632-637.

66 Cidis MB, Warshowsky JH, Goldrich SG, Meltzer CC. Mirror-image optic nerve dysplasia with associated anisometropia in identical twins. J Am Optom Assoc 1997; 68: 325-329.

67 Hackenbruch Y, Meerhoff E, Besio R, Cardoso H. Familial bilateral optic nerve hypoplasia. Am J Ophthalmol 1975; 79: 314-320.

68 Beuchat L, Safran AB. Optic nerve hypoplasia: papillary diameter and clinical correlation. J Clin Neuroophthalmol 1985; 5: 249-253.

69 Novak JM, McLaren P. Optic nerve hypoplasia. J Am Optom Assoc 1987; 58: 122-126.

70 Hellstrom A, Wiklund LM, Svensson E, AlbertssonWikland K, Stromland K. Optic nerve hypoplasia with isolated tortuosity of the retinal veins: a marker of endocrinopathy. Arch Ophthalmol 1999; 117: 880-884.

71 Brodsky MC, Buckley EG, McConkie-Rosell A. The case of the gray optic disc!. Surv Ophthalmol 1989; 33: 367-372.
72 Wakakura M, Alvarez E. A simple clinical method of assessing patients with optic nerve hypoplasia. The discmacula distance to disc diameter ratio (DM/DD). Acta Ophthalmol (Copenh) 1987; 65: 612-617.

73 Alvarez E, Wakakura M, Khan Z, Dutton GN. The disc-macula distance to disc diameter ratio: a new test for confirming optic nerve hypoplasia in young children. J Pediatr Ophthalmol Strabismus 1988; 25: 151-154.

74 Zeki SM, Dudgeon J, Dutton GN. Reappraisal of the ratio of disc to macula/disc diameter in optic nerve hypoplasia. Br J Ophthalmol 1991; 75: 538-541.

75 Barr DB, Weir CR, Purdie AT. An appraisal of the disc-macula distance to disc diameter ratio in the assessment of optic disc size. Ophthalmic Physiol Opt 1999; 19: 365-375.

76 Borchert M, McCulloch D, Rother C, Stout AU. Clinical assessment, optic disk measurements, and visual-evoked potential in optic nerve hypoplasia. Am J Ophthalmol 1995; 120: 605-612.

77 Zeki SM. The brightness-sense comparison in patients with optic nerve hypoplasia. Acta Ophthalmol (Copenh) 1991; 69: 649-653.

78 Sprague JB, Wilson WB. Electrophysiologic findings in bilateral optic nerve hypoplasia. Arch Ophthalmol 1981; 99: 1028-1029.

79 Bjork A, Laurell CG, Laurell U. Bilateral optic nerve hypoplasia with normal visual acuity. Am J Ophthalmol 1978; 86: 524-529.

80 Purvin VA. Superior segmental optic nerve hypoplasia. J Neuroophthalmol 2002; 22: 116-117.

81 Unoki K, Ohba N, Hoyt WF. Optical coherence tomography of superior segmental optic hypoplasia. $\mathrm{Br} \mathrm{J}$ Ophthalmol 2002; 86: 910-914.

82 Boynton JR, Pheasant TR, Levine MR. Hypoplastic optic nerves studied with B-scan ultrasonography and axial tomography of the optic canals. Can J Ophthalmol 1975; 10: 473-481.

83 Hellstrom A, Wiklund LM, Svensson E. Diagnostic value of magnetic resonance imaging and planimetric measurement of optic disc size in confirming optic nerve hypoplasia. J AAPOS 1999; 3: 104-108.

84 Brodsky MC, Glasier CM, Pollock SC, Angtuago EJ. Optic nerve hypoplasia. Identification by magnetic resonance imaging. Arch Ophthalmol 1990; 108: 1562-1567.

85 Brodsky MC, Glasier CM. Optic nerve hypoplasia. Clinical significance of associated central nervous system abnormalities on magnetic resonance imaging. Arch Ophthalmol 1993; 111: 66-74.

86 Williams J, Brodsky MC, Griebel M, Glasier CM, Caldwell D, Thomas P. Septo-optic dysplasia: the clinical insignificance of an absent septum pellucidum. Dev Med Child Neurol 1993; 35: 490-501.

87 Barkovich AJ, Fram EK, Norman D. Septo-optic dysplasia: MR imaging. Radiology 1989; 171: 189-192.

88 Burke JP, O'Keefe M, Bowell R. Optic nerve hypoplasia, encephalopathy, and neurodevelopmental handicap. $\mathrm{Br} \mathrm{J}$ Ophthalmol 1991; 75: 236-239.

89 Willnow S, Kiess W, Butenandt O, Dorr HG, Enders A, Strasser-Vogel B et al. Endocrine disorders in septo-optic dysplasia (De Morsier syndrome) — evaluation and follow up of 18 patients. Eur J Pediatr 1996; 155: 179-184.

90 Traggiai C, Stanhope R. Endocrinopathies associated with midline cerebral and cranial malformations. J Pediatr 2002; 140: 252-255. 
91 Kaufman FR, Costin G, Thomas DW, Sinatra FR, Roe TF, Neustein HB. Neonatal cholestasis and hypopituitarism. Arch Dis Child 1984; 59: 787-789.

92 Arslanian SA, Rothfus WE, Foley Jr TP, Becker DJ. Hormonal, metabolic, and neuroradiologic abnormalities associated with septo-optic dysplasia. Acta Endocrinol (Copenh) 1984; 107: 282-288.

93 Sherlock DA, McNicol LR. Anaesthesia and septo-optic dysplasia. Implications of missed diagnosis in the perioperative period. Anaesthesia 1987; 42: 1302-1305.

94 Gilbert JD, Scott G, Byard RW. Septo-optic dysplasia and unexpected adult death - an autopsy approach. J Forensic Sci 2001; 46: 913-915.

95 Nanduri VR, Stanhope R. Why is the retention of gonadotrophin secretion common in children with panhypopituitarism due to septo-optic dysplasia? Eur J Endocrinol 1999; 140: 48-50.

96 Levine LM, Bhatti MT, Mancuso AA. Septo-optic dysplasia with olfactory tract and bulb hypoplasia. J AAPOS 2001; 5 398-399.

97 Skarf B, Hoyt CS. Optic nerve hypoplasia in children. Association with anomalies of the endocrine and CNS. Arch Ophthalmol 1984; 102: 62-67.

98 Yang LL, Lambert SR. Reappraisal of occlusion therapy for severe structural abnormalities of the optic disc and macula. J Pediatr Ophthalmol Strabismus 1995; 32: 37-41.

99 Zeki SM. Optic nerve hypoplasia and astigmatism: a new association. Br J Ophthalmol 1990; 74: 297-299.

100 Fielder AR, Fulton AB, Mayer DL. Visual development of infants with severe ocular disorders. Ophthalmology 1991; 98: 1306-1309.

101 Jacobson LK, Dutton GN. Periventricular leukomalacia: an important cause of visual and ocular motility dysfunction in children. Surv Ophthalmol 2000; 45: 1-13.

102 Cowey A. Atrophy of retinal ganglion cells after removal of striate cortex in a rhesus monkey. Perception 1974; 3 . 257-260.

103 Weller RE, Kaas JH, Wetzel AB. Evidence of the loss of $X$ cells of the retina after long term ablation of visual cortex in monkeys. Brain Res 1979; 160: 134-138.

104 Dineen JT, Hendrickson AE. Age correlated differences in the amount of retinal degeneration after striate cortex lesions in monkeys. Invest Ophthalmol Vis Sci 1981; 21: 749-752.

105 Sonksen P, Stiff B. Show Me What my Friends Can See. Stillmans Communications: Nottingham, 1999.

106 Carney SH, Brodsky MC, Good WV, Glasier CM, Greibel ML, Cunniff C. Aicardi syndrome: more than meets the eye. Surv Ophthalmol 1993; 37: 419-424.

107 Hoyt CS, Billson FA. Maternal anticonvulsants and optic nerve hypoplasia. Br J Ophthalmol 1978; 62: 3-6.

108 Russell-Eggitt IM, Blake KD, Taylor DS, Wyse RK. The eye in the CHARGE association. Br J Ophthalmol 1990; 74: 421-426.

109 Schafer IA, Robin NH, Posch JJ, Clark BA, Izumo S, Schwartz S. Distal $5 q$ deletion syndrome: phenotypic correlations. Am J Med Genet 2001; 103: 63-68.

110 Denslow GT, Sims M. Duane's retraction syndrome associated with optic nerve hypoplasia. J Pediatr Ophthalmol Strabismus 1980; 17: 26-28.

111 Walsh LM, Lynch SA, Clarke MP. Ocular abnormalities in a patient with partial deletion of chromosome $6 \mathrm{p}$. A case report. Ophthalmic Genet 1997; 18: 151-156.

112 Stratton RF, DuPont BR, Mattern VL, Schelonka RL, Moore CM. Interstitial duplication of 7(q22->q34). Am J Med Genet 1993; 47: 380-382.
113 Keith CG, Webb GC, Rogers JG. Absence of a lateral rectus muscle associated with duplication of the chromosome segment 7q32-q34. J Med Genet 1988; 25: 122-125.

114 Sawada K, Sakata-Haga H, Komatsu S, Ohta K, Jeong YG, Fukui Y. A selective loss of small-diameter myelinated optic nerve axons in rats prenatally exposed to ethanol Congenit Anom Kyoto 2002; 42: 125-129.

115 Roarty JD, Pron GE, Siegel-Bartelt J, Posnick JC, Buncic JR. Ocular manifestations of frontonasal dysplasia. Plast Reconstr Surg 1994; 93: 25-30.

116 Margolis S, Aleksic S, Charles N, McCarthy J, Greco A, Budzilovich G. Retinal and optic nerve findings in Goldenhar-Gorlin syndrome. Ophthalmology 1984; 91: 1327-1333.

117 Hamilton J, Blaser S, Daneman D. MR imaging in idiopathic growth hormone deficiency. Am J Neuroradiol 1998; 19: 1609-1615.

118 Fraunfelder FT, LaBraico JM, Meyer SM. Adverse ocular reactions possibly associated with isotretinoin. Am J Ophthalmol 1985; 100: 534-537.

119 Katz B, Wiley CA, Lee VW. Optic nerve hypoplasia and the syndrome of nevus sebaceous of Jadassohn. A new association. Ophthalmology 1987; 94: 1570-1576.

120 Nelson M, Lessell S, Sadun AA. Optic nerve hypoplasia and maternal diabetes mellitus. Arch Neurol 1986; 43: 20-25.

121 Zervos A, Hunt KE, Tong HQ, Avallone J, Morales J, Friedman $\mathrm{N}$ et al. Clinical, genetic and histopathologic findings in two siblings with muscle-eye-brain disease. Eur J Ophthalmol 2002; 12: 253-261.

122 Fard AK, Traboulsi EI. Coloboma of the lens, optic nerve hypoplasia, and orbital hemangioma - a possible developmental field defect. Ophthalmic Genet 1998; 19 209-212.

123 Lee JT, Hall TR, Bateman JB. Optic nerve hypoplasia secondary to intracranial teratoma. Am J Ophthalmol 1997; 124: 705-706.

124 McMahon CL, Braddock SR. Septo-optic dysplasia as a manifestation of valproic acid embryopathy. Teratology 2001; 64: 83-86.

\section{Appendix A}

Organisations providing help for families with children with visual impairment.

\section{Specific organisations}

(1) Focus (Septo Optic Dysplasia/Optic Nerve

Hypoplasia)

E-mail: uksupport@focusfamilies.org

Website: www.focusfamilies.org

(2) MACS (Micro \& Anophthalmic Children's Society) Coloboma is one of the eye conditions covered by MACS MACS

1 Skyrmans Fee

Frinton-on-Sea

CO13 0RN

Tel/Fax: 08706006227

E-mail: enquiries@macs.org.uk

Website: http:/ /www.macs.org.uk 
(3) Eyeless Trust

Eyeless Trust

PO Box 1248

Slough

SL2 3GH

Tel: 01494672006

E-mail: ANDREW.paul@eyeless.org.uk

Website: http:/ /www.eyeless.org.uk

\section{General organisations helping families with visual impairment}

(1) Visual Impairment Scotland

Visual Impairment Scotland is a new organisation that aims to provide information and support to children with visual impairments and their parents. Clear and understandable medical information documents are provided as well as a parent network support system.

Tel: 01316516078

E-mail: viscotland@ed.ac.uk

Website: www.viscotland.org.uk

(2) Specific Eye Conditions (SPECS)

SPECS provides support to a wide range of organisations dedicated to helping people with eye conditions. The website provides a directory for patients, parents, and clinicians who are looking for information and support.

Specific Eye Conditions, PO Box 379, Margate CT9 1WD

Tel: 01843292435

E-mail: info@eyeconditions.org.uk

Website: www.eyeconditions.org.uk

(3) Contact a Family

Contact a Family is a national registered charity, founded in 1979, for families with disabled children.
Contact a Family's aim is to enable families to organise their own systems of support and contact. Contact a Family, 209-211 City Road, London EC1 V 1JN Tel: 0207608 8700; Fax 02076088701

Helpline: 08088083555 or Textphone: 0808808 3556; Freephone for parents and families (1000-1600 hours, Mon-Fri)

E-mail: info@cafamily.org.uk

Website: http://www.cafamily.org.uk

(4) The National Blind Children's Society

This is a national organisation that offers a wide range of services to visually impaired people aged between 0 and 24.

NBCS, Bradbury House, Market Street, Highbridge, Somerset TA9 3BW

Tel: 01278764764

E-mail: enquires@nbcs.org.uk

Website: www.nbcs.org.uk

(5) Look

Look is a parent-run organisation that was established to give mutual support to families of visually impaired children. There are local UK branches.

LOOK, 49 Court Oak Road, Birmingham B17 9TG Tel: 01214285038

Website: www.look-uk.org

(6) Royal National Institute of the Blind (RNIB) The RNIB offers a wide range of family support services.

105 Judd Street, London WC1 H 9NE

Telephone Helpline: 08457669999 (for the price of a local call, UK callers only)

Tel: 02073881266 (switchboard/overseas callers)

Fax: 02073882034

Website: www.rnib.org.uk 